DOI: $10.17805 /$ zpu.2017.1.16

\title{
Академическая терминология британского и американского вариантов английского языка
}

\author{
3. Х. ФАЗЛЫЕВА, Н. О. САМАРКИНА \\ КАЗАНСКИЙ (ПРИВОЛЖСКИЙ) ФЕДЕРАЛЬНЫЙ УНИВЕРСИТЕТ
}

Статья посвящена сопоставительному рассмотрению академической, т. е. относящейся к области высшего образования, терминологии в двух наиболее распространенных вариантах английского языка - британском и американском. Для ученого сообщества, в том числе России, многие термины представляют трудности для понимания и перевода из-за различий в их определении и некоторых особенностей системы образования в рассматриваемых странах.

Основной причиной существования таких несоответствий можно считать обособленное развитие американского варианта в течение длительного исторического периода. Не всегда можно найти прямые аналогии тому или иному термину, однако отправной точкой исследования можно считать некий общий стандарт академических понятий. Словари не дают полной картины терминологических различий, поэтому к исследованию были привлечены материалы корпусов англоязычных текстов, а также научная информация с англоязычных университетских сайтов. Это дало возможность наблюдать поведение языковых единиц в естественной и синхронной и действительно существующей языковой среде.

Материал исследования скомпонован в виде таблиц, наглядно демонстрирующих терминологию британского или американского вариантов английского языка в области высшей школы. Проведенный анализ семантики терминологических единиц позволил выделить лексико-семантические аналогии и лексико-семантические дивергенты в терминологии изучаемых национальных вариантов.

Несмотря на особенности развития двух рассматриваемых вариантов английского языка, их общеязыковой фундамент не позволяет достичь ярко выраженной вариативности терминологических единиц. 
Ключевые слова: высшая школа; английский язык; британский вариант; американский вариант; сопоставительный анализ; структура университета; академическая терминология; лексико-семантические варианты; дивергенты

\section{ВВЕАЕНИЕ}

$\mathrm{B}$ данной статье мы рассматриваем термины английского языка, относящиеся к сфере высшей школы, т. е. академические (академический - учебный, применительно к высшим учебным заведениям (Ожегов, 2006)). Исследование носит сопоставительный характер, поскольку изучению подлежат академические термины двух установленных вариантов английского языка - британского и американского. При этом под термином понимается специальное слово и выражение, принятое для обозначения чего-нибудь в той или иной среде, профессии, основное средство выражения научного понятия (Толковый словарь русского языка, 2000: 689).

Сотрудничество между российскими и зарубежными университетами требует владения академической терминологией на профессиональном уровне. Но многие термины представляют трудности для понимания и перевода, поскольку существует разнобой в их определении и из-за различий систем образования в рассматриваемых странах (Митчел, Маругина, 2015). При этом следует учитывать лексико-семантическую дифференциацию в британском и американском вариантах английского языка. Известно, что в системах британского и американского вариантов английского языка наблюдаются многочисленные расхождения на всех языковых уровнях - фонемном, морфемном, синтаксическом, однако именно лексический уровень языка, будучи наиболее открытым, подвергается наибольшим метаморфозам. Основной причиной существования таких несоответствий следует считать довольно независимое и обособленное развитие американского варианта в течение длительного исторического периода, т. е. межрегионально обусловленные закономерности возникновения терминов в британском и американском культурных социумах (Семенова, 2011: 79), а также стремление обеих стран - Англии и Америки - к индивидуализации. Полному расхождению и обособлению в отдельные языки мешает международный статус английского языка.

Вопросам вариативности английского языка, вызванной социальными, функциональными и территориальными факторами, посвящено много работ как в отечественной, так и зарубежной лингвистике (А. Г. Попова, А. И. Смирницкий, Г. В. Степанов, Г. А. Томахин, А. И. Чередниченко, А. А. Швейцер, Г. С. Щур, В. Н. Ярцева, R. Вailey, D. Crystal, W. Labov и Ap.). Интерес к проблеме объясняется неоднородностью и сложностью языкового состава, особенностями его функционирования в различных языковых ситуациях и территориальных ареалах.

Актуальность исследования заключается в необходимости осветить и разрешить проблему выявления терминологических различий двух основных диалектов английского языка в сфере высшей школы. Ранее языковеды уделяли больше внимания выявлению этимологических несоответствий между американским и британским вариантами, чем выявлению соотношения между ними в современном, по состоянию на сегодня, языке. Этот язык наиболее полно, объемно и достоверно представлен, например, в многочисленных уже лингвистических корпусах.

Использование корпусов текстов дает возможность наблюдать поведение интересующих исследователя языковых единиц в естественной и синхронной языковой среде, т. е. в реально существующих, а не искусственно сконструированных контекстах. Помимо корпусов национального русского языка, британского английского языка, а также современного американского варианта английского языка (Национальный 
корпус русского языка (НКРЯ) (http://www.ruscorpora.ru/), на русском, потом в оригинале - British National Corpus (BYU-BNC) (http://www.natcorp.ox.ac.uk/), на pусском - Corpus of Contemporary American English (COCA) (URL: http://corpus.byu. $\mathrm{edu} / \mathrm{coca} /$ ), на русском - News on the Web Corpus (NOW Corpus) (http://corpus.byu. edu/now), мы активно использовали терминологический материал с сайтов зарубежных университетов: Университета Гарварда (Harvard University), Университета Принстона (Princeton University), Государственного университета Флориды (Florida State University), Нью-Йоркского университета (New York University), университетов Оксфорда и Кембриджа (Oxbridge), Университета Манчестера (The University of Manchester), Университета $\Lambda$ анкастера (Lancaster University) и т. А.

В работе были использованы методы: теоретический анализ научно-методической литературы; практический анализ терминоупотреблений на материале лингвистических корпусов (британского и американского вариантов английского языка) и академических текстов; сравнительно-синхронный метод.

Целью нашего исследования является выявление различий академической терминологии британского и американского вариантов английского языка на примерах из академических текстов, взятых из языковых корпусов и университетских документов в открытом доступе, поскольку словари не дают полной необходимой информации. Объектом исследования выступает академическая терминология английского языка, а предметом исследования - различия в данной терминологии британского и американского вариантов английского языка. Метаязыком работы служит русский язык.

\section{СИСТЕМА ВЫСШЕГО ОБРАЗОВАНИЯ В ВЕАИКОБРИТАНИИ И США}

Обратимся к структуре высшего образования в обеих рассматриваемых странах. Одной из древнейших в Европе является система высшего образования в Англии. Основной образовательной единицей здесь выступает колледж (самостоятельный вуз или часть университета), подразделяемый на факультеты и кафедры. Имеются институты как самостоятельные вузы и институты как конгломераты отдельных колледжей.

Британские университеты присуждают три вида ученых степеней: бакалавр, магистр и доктор по соответствующей специальности. Первой университетской степенью является степень бакалавра искусств (Bachelor of Arts, BA) или наук (Bachelor of Science, BSc). Второй более высокой степенью является степень магистра искусств (Master of Arts, MA) или наук (Master of Science, MSc). После степеней бакалавра и магистра в британских университетах следует степень магистра философии (Master of Philosophy, M.Phil.). Степень магистра философии является промежуточной между степенью магистра и доктора философии и может быть присуждена по любой из имеющихся в университете специальностей. Степень доктора философии (Doctor of Philosophy, $\mathrm{PhD}$ ) - самая высокая степень, присуждаемая в британских университетах. Некоторые университеты своим выпускникам за особо ценные докторские диссертации присуждают ученые степени более высокого ранга - доктора гуманитарных наук (Doctor of Letters, D.Litt.) и доктора естественных наук (Doctor of Science, D.Sc.) (Сулейманова, 2009: 135).

В США основой системы подготовки научных кадров является британская система. В высшей школе США принято выделять три уровня образования: первый уровень достигается в двухгодичных общеобразовательных учебных заведениях, имеющих право на присвоение профессиональной степени ассоциата (Associate's degree); 
второй уровень достигается в четырехлетних колледжах гуманитарных и естественных направлений и сопровождается присуждением степени бакалавра; третий уровень достигается в аспирантских и высших профессиональных школах колледжей и университетов и сопровождается присуждением степени магистра и доктора. Подготовка специалистов высшей квалификации и научных работников в рамках высшей школы и системы повышения квалификации в США осуществляется в отделениях и на курсах последипломной подготовки университетов и колледжей, в исследовательских школах, профессиональных школах II ступени, функционирующих при университетах или самостоятельно. Существует два наиболее общих типа степени бакалавра бакалавр гуманитарных наук (Bachelors in Arts, В. А.) и бакалавр наук (Bachelors in Science, B. S.). Высшей академической степенью, присваиваемой в Соединенных Штатах, является степень доктора философии (PhD) (Мариносян, 2014: 87).

Приведенные сведения о двух типах высшего образования позволяют разобраться как в общей системе университетского образования в изучаемых странах, так и знакомят с академической терминологией этих метрополий.

\section{СРАВНИТЕАЬНАЯ АЕКСИКО-СЕМАНТИЧЕСКАЯ ХАРАКТЕРИСТИКА АКАДЕМИЧЕСКИХ ТЕРМИНОВ АНГАИЙСКОГО ЯЗЫКА}

Теперь перейдем непосредственно к терминологии, употребляемой в научно-образовательной сфере метрополии и США. Естественно, что каждая страна обладает своей специфичной системой высшего образования, и не всегда можно найти прямые аналогии тому или иному термину. Однако существует некая увековеченная «база», некий стандарт академических понятий (Амитриев, 2010: 262-266). Оговоримся, что в данной статье мы не рассматриваем разговорную академическую терминологию, такую, например, как varsity ( «университет» разг.) или fresher ( «первокурсник» разг.). Аля удобства исследования скомпонуем соответствующую терминологию по категориям.

1. Структура университета и основные подразделения / University structure and the main subdivisions.

2. Органы управления и должностные лица / Authorities and Officials.

3. Высшее образование. Высшие квалификации / Higher education. Higher degrees.

4. Научно-педагогические кадры / University teaching staff.

5. Студенты / Classification of students.

За основу классификации составляющих высшего учебного заведения берется система британских вузов, поскольку она является базовой, классической и общепризнанной, на основе которой строятся структурные модификации других англоязычных вузов, в нашем случае - американских.

Рассмотрим табл. 1 (с. 212). Приведенные здесь примеры взяты из лингвистических корпусов, а также с сайтов британских и американских университетов. Поскольку упомянутые источники содержат невымышленный газетный, журнальный и документальный материал, соответственно, имена, имеющие место в примерах, реальны.

В табл. 1 дается представление об основных вузовских подразделениях. В ней мы попытались сопоставить академические термины двух исследуемых вариантов английского языка. Русский язык выступает метаязыком разработки. Налицо два основных типа лексико-семантических вариантов - лексико-семантические аналоги, когда при общности в плане выражения различается план содержания, и лексико-семантические дивергенты (Швейцер, 1988), когда разнится план выражения при общности в плане содержания. Например, основное понятие «university» в американском 
СТРУКТУРА УНИВЕРСИТЕТА И ОСНОВНЫЕ ПОАРАЗАЕАЕНИЯ

UNIVERSITY STRUCTURE AND THE MAIN SUBDIVISIONS

Tabl. 1

\begin{tabular}{|c|c|c|}
\hline $\begin{array}{c}\text { Английский язык } \\
\text { (британский Вариант) }\end{array}$ & Русский языю & $\begin{array}{c}\text { Английский язьк } \\
\text { (американский вариант) }\end{array}$ \\
\hline $\begin{array}{l}\text { Educational Institution: The library is } \\
\text { just one department within an educa- } \\
\text { tional institution }\end{array}$ & $\begin{array}{l}\text { Образовательное } \\
\text { учреждение }\end{array}$ & $\begin{array}{l}\text { Educational Institution: Success of } \\
\text { any educational institution depends } \\
\text { on the type of administration and its } \\
\text { capabilities to drive the preplanned } \\
\text { goals within the time framework set } \\
\text { forth }\end{array}$ \\
\hline $\begin{array}{l}\text { University: She was noticed at York } \\
\text { University } 12 \text { days ago, after arriving } \\
\text { to teach English to Open University } \\
\text { students }\end{array}$ & $\mathrm{y}_{\text {ниверситет }}$ & $\begin{array}{l}\text { University } \backslash \text { College: The process of } \\
\text { tenure at the university level includes } \\
\text { not only a probationary period of at } \\
\text { least } 5 \text { years, but also proof of teach- } \\
\text { ing expertise. } \backslash \text { The college offers doc- } \\
\text { toral programs in chemistry and } \\
\text { chemical engineering }\end{array}$ \\
\hline $\begin{array}{l}\text { School } \backslash \text { Institute: Management School } \\
\text { Building, Lancaster University. } \\
\text { Four fully-funded studentships from } \\
\text { the National Institute for Health } \\
\text { Research (NIHR) will be awarded to } \\
\text { students studying the MSc in Statistics }\end{array}$ & Институт & $\begin{array}{l}\text { School } \backslash \text { Institute: Moving rapidly } \\
\text { through school, he graduated Phi Beta } \\
\text { Kappa from the University of } \\
\text { Kentucky at age 18. It is an elite } \\
\text { research institute devoted to computer } \\
\text { software }\end{array}$ \\
\hline $\begin{array}{l}\text { College: All my friends were going to } \\
\text { college or getting jobs }\end{array}$ & Кол. & $\begin{array}{l}\text { College: Even in college, students omit } \\
\text { formal connectives in conversation }\end{array}$ \\
\hline $\begin{array}{l}\text { Faculty: Staff would be appointed not } \\
\text { to this or that department or faculty, } \\
\text { but simply to the institution }\end{array}$ & $\begin{array}{l}\text { Профессорско- } \\
\text { преподавательский } \\
\text { состав }\end{array}$ & $\begin{array}{l}\text { Professional and teaching staff: In } \\
\text { our university professional and teach- } \\
\text { ing staff include well-known names }\end{array}$ \\
\hline $\begin{array}{l}\text { Admissions Office: They've bad a very } \\
\text { busy summer in the Admissions } \\
\text { Office, but now the new academic } \\
\text { year is underway, I've invited them } \\
\text { into the studio to ask them about this } \\
\text { year's admissions }\end{array}$ & $\begin{array}{l}\text { Приемная } \\
\text { комиссия }\end{array}$ & $\begin{array}{l}\text { Admissions Office: According to the } \\
\text { Admission office, applications were } \\
\text { up by } 20 \text { percent in } 2005 \text {, and another } \\
15 \text { percent this year }\end{array}$ \\
\hline $\begin{array}{l}\text { Campus: The school is situated witbin } \\
\text { the mature park of a campus universi- } \\
\text { ty and its location offers excellent } \\
\text { communications by road, rail and air }\end{array}$ & $\begin{array}{l}\text { Кампус, террито- } \\
\text { рия университета, } \\
\text { университетский } \\
\text { городок }\end{array}$ & $\begin{array}{l}\text { Campus: Later in the day, students } \\
\text { went on a walking tour of the campus } \\
\text { by sections }\end{array}$ \\
\hline $\begin{array}{l}\text { Library: There are almost as many } \\
\text { kinds of libraries as there are kinds of } \\
\text { readers }\end{array}$ & Библиотека & $\begin{array}{l}\text { Library: The library was a vast square } \\
\text { room with dark wood from floor to } \\
\text { ceiling }\end{array}$ \\
\hline
\end{tabular}

Примечание: здесь и в следующих таблицах примеры из лингвистических корпусов и материалов с англоязычных университетских сайтов выделены курсивом; жирным шрифтом выделены сами термины. 
варианте дополняется термином «college». Последний представляет пример двусторонней локальной маркированности, когда при наличии общеанглийских значений «специальное высшее учебное заведение и факультет» американский термин расширяет свое значение до понятия «университет». Примером односторонней локальной маркированности служит термин «второкурсник» - «sophomore», специфичный для американского варианта английского языка.

Рассмотрим лексико-семантические дивергенты «professional and teaching staff» (бритицизм) и «faculty» (американизм) со значением «профессорско-преподавательский состав». Британское понятие имеет прямое значение, тогда как американское переосмыслено из понятия «учебно-научное и административное структурное подразделение высшего учебного заведения» на основе словообразовательной связи. Таким образом, налицо процесс переноса значения.

Конечно же, нужно учитывать вероятность взаимопроникновения и взаимовлияния двух сравниваемых языковых вариантов и понимать, что указанный американизм вполне может быть использован носителями британского английского, но в данном конкретном случае за основу берутся әлементы в «чистом виде».

А вот, к примеру, термин «сатрus»- это американская реалия, перенесенная на почву британского варианта языка.

С управленческим аппаратом вуза знакомит табл. 2 (с. 214).

Примеры, приведенные из языковых корпусов, убеждают, что практически каждая должность имеет разночтения в британском и американском английском. Так, понятие «администрация вуза» в сравниваемых языковых вариантах имеет не только общее толкование «University Senate», но и специфичные для каждого варианта синонимы — «General Council» - для британского и дополнительный «Corporation» - для американского английского. Речь идет о главном административном органе управления вуза. Интересно то, что «Corporation»- слово британского происхождения, но нужно учитывать, что в начале раннего периода английский язык в Америке в основном соответствовал тем нормам, которые были приняты в Англии в XVII в. Таким образом, некоторая лексика американского английского как бы застыла в своем развитии или изменилась незначительно.

«Supervisory board»- попечительский совет университета. Он принимает решения о количестве и природе факультетов, научных центров, решает вопросы о специальностях и квалификациях, присваиваемых университетом. В американском варианте это - «Board of Trustees», «Board of Regents» или «Board of Overseers», где trustees, regents и overseers - это «попечители» или «наблюдатели». Как видим, различия в формулировке не очень сильны, и они вызваны особой у каждого народа понятийной картиной мира.

«Ректор университета» при общеязыковом - «Chancellor», с базовым значением «начальник, глава, патрон» - имеет лексико-семантические дивергенты «Principal»- в британском и «President» - в американском английском. Последнее происходит из среднеанглийского со значением «глава церкви или университета», т. е. имеет довольно раннюю этимологию.

«Проректор»в британском варианте звучит как «vice-chancellor», а в американском - «provost». Оба лексических дивергента имеют древнее происхождение, причем «provost» - древнеанглийское, т. е. опять же приходим к выводу об архаичности, по крайней мере некоторой, американской лексики.

В табл. 3 (с. 215) представлена терминология высших вузовских квалификаций. 


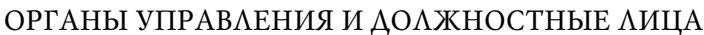

AUTHORITIES AND OFFICIALS

Tabl. 2

\begin{tabular}{|c|c|c|}
\hline $\begin{array}{c}\text { Английский язьюк } \\
\text { (британский Вариант) }\end{array}$ & Русский языюк & $\begin{array}{c}\text { Английский язькк } \\
\text { (американский вариант) }\end{array}$ \\
\hline $\begin{array}{l}\text { (General) Council } \backslash \text { University Senate: } \\
\text { The University Council is the execu- } \\
\text { tive governing body, responsible for } \\
\text { the management and administration } \\
\text { of our revenue and property. } \backslash \text { She put } \\
\text { ber name down to speak in the great } \\
\text { debate about the state of the English } \\
\text { Faculty that was beld in the } \\
\text { University Senate }\end{array}$ & $\begin{array}{l}\text { Администрация } \\
\text { вуза }\end{array}$ & $\begin{array}{l}\text { University Senate \Corporation } \backslash \\
\text { Chairman of the University Senate. } \backslash \\
\text { The oldest corporation in the Western } \\
\text { Hemisphere is the Harvard } \\
\text { Corporation, known formally as the } \\
\text { President and Fellows of Harvard } \\
\text { College }\end{array}$ \\
\hline $\begin{array}{l}\text { Supervisory board: Most supervisory } \\
\text { boards meet only twice a year }\end{array}$ & $\begin{array}{l}\text { Попечительский } \\
\text { совет }\end{array}$ & $\begin{array}{l}\text { Board of trustees } \backslash \text { Board of Regents } \\
\backslash \text { Board of Overseers: We should } \\
\text { invite the Board of Trustees of the } \\
\text { Institute to rationalize the financial } \\
\text { structure of the Institute. } \backslash \text { The Board } \\
\text { of Regents, the governing body for } \\
\text { The University of Texas System, is } \\
\text { composed of nine members. } \backslash \text { Members } \\
\text { of the Board of Overseers are elected } \\
\text { by the university degree bolders }\end{array}$ \\
\hline $\begin{array}{l}\text { Dean's office } \backslash \text { Dean office: It is envis- } \\
\text { aged to react on strengthening of the } \\
\text { requirements from dean's offices with } \\
\text { respect to individual teachers }\end{array}$ & Аеканат & $\begin{array}{l}\text { Dean's office } \backslash \text { Dean office: The Dean's } \\
\text { Office sets the school's strategic } \\
\text { direction and leads its efforts to } \\
\text { advance the public interest }\end{array}$ \\
\hline $\begin{array}{l}\text { Chair, department: Mr Jones took the } \\
\text { chair. It is one of the UK's top } \\
\text { departments for research in mathe- } \\
\text { matics and statistics }\end{array}$ & Кафедра & $\begin{array}{l}\text { Chair, department: Head of the politi- } \\
\text { cal economy chair at the Moscow } \\
\text { Machinery Institute. } \backslash \text { Additionally, } \\
\text { students may take courses offered by } \\
\text { other departments in the Faculty of } \\
\text { Arts \& Sciences }\end{array}$ \\
\hline $\begin{array}{l}\text { Chancellor } \backslash \text { Principal: Sean } \\
\text { Moorbead received one of the } \\
\text { Chancellor's Medals, which is pre- } \\
\text { sented annually for exceptional per- } \\
\text { formance at undergraduate and post- } \\
\text { graduate levels. } \backslash \text { The principal bad } \\
\text { overruleed the lecturers' proposals }\end{array}$ & Ректор & $\begin{array}{l}\text { Chancellor } \backslash \text { President: The bead of } \\
\text { some American universities is called } \\
\text { the Chancellor. } \backslash \text { The University } \\
\text { President will bold a news conference } \\
\text { tomorrow }\end{array}$ \\
\hline $\begin{array}{l}\text { Vice-chancellor: Peter H. Katjavivi, } \\
\text { Founding Vice-Chancellor, } \\
\text { University of Namibia, Windboek }\end{array}$ & Проректор & $\begin{array}{l}\text { Provost: The provost works with the } \\
\text { president to oversee academic policies } \\
\text { and activities university-wide }\end{array}$ \\
\hline $\begin{array}{l}\text { Director: Ghassan Faramand, } \\
\text { Director, Law Institute, Birzeit }\end{array}$ & $\begin{array}{l}\text { Аиректор } \\
\text { института }\end{array}$ & $\begin{array}{l}\text { Director: Pascal Boniface is Director } \\
\text { of the Institute for International and } \\
\text { Strategic relations, Paris }\end{array}$ \\
\hline
\end{tabular}


ВЫСШЕЕ ОБРАЗОВАНИЕ. ВЫСШИЕ КВААИФИКАЦИИ

Таблица 3

HIGHER EDUCATION. HIGHER DEGREES

Tabl. 3

\begin{tabular}{|c|c|c|}
\hline $\begin{array}{l}\text { Английский язык } \\
\text { (британский Baриант) } \\
\text { Baccalaureate } \backslash \text { Bachelor's Degree } \backslash \\
\text { Undergraduate level (course): There } \\
\text { was also one student who bad taken } \\
\text { the Baccalaureate - a combination } \\
\text { of ten subjects, arts and science. } \\
\text { Undergraduate students may gradu- } \\
\text { ate with a Bachelor of Science deg- } \\
\text { ree (BSc) after three years of study. } \\
\backslash \text { Learn about undergraduate-level } \\
\text { CPD course units at The University } \\
\text { of Manchester's School of Nursing }\end{array}$ & \begin{tabular}{|l}
$\quad$ Русский язык \\
Бакалавриат \\
(форма трех- или \\
пятигодичного \\
обучения студентов, \\
дающая базовое высшее \\
образование и степень \\
бакалавра)
\end{tabular} & $\begin{array}{l}\quad \text { Английский язык } \\
\qquad \text { (американский Bариант) } \\
\text { Baccalaureate } \backslash \text { Bachelor's Degree } \backslash \\
\text { Undergraduate program (study): } \\
\text { This list includes many post bacca- } \\
\text { laureate and special masters pro- } \\
\text { grams around the country. } \backslash \text { All } \\
\text { students obtain a bachelor's degree } \\
\text { before admission to medical school. } \\
\text { The undergraduate linguistics pro- } \\
\text { gram at Berkeley offers students a } \\
\text { unique opportunity to study an inte- } \\
\text { resting and challenging discipline }\end{array}$ \\
\hline $\begin{array}{l}\text { Master's course: In November } 2015 \\
\text { the UK Government confirmed that } \\
\text { a new postgraduate loan scheme will } \\
\text { be introduced for students com- } \\
\text { mencing Masters courses in the } \\
\text { 2016/17 academic year }\end{array}$ & $\begin{array}{l}\text { Магистратура (ступень } \\
\text { высшего профессио- } \\
\text { нального образования, } \\
\text { следующая после бака- } \\
\text { лавриата, позволяющая } \\
\text { углубить специализацию } \\
\text { по определенному про- } \\
\text { фессиональному на- } \\
\text { правлению и дающая } \\
\text { степень магистра) }\end{array}$ & $\begin{array}{l}\text { Master's program (study): Choose } \\
\text { from } 13 \text { yearlong intensive master's } \\
\text { programs exploring the most chal- } \\
\text { lenging and exciting questions in } \\
\text { education research }\end{array}$ \\
\hline $\begin{array}{l}\text { Postgraduate study: We offer a } \\
\text { variety of opportunities for post- } \\
\text { graduate study in mathematics and } \\
\text { statistics, including postgraduate } \\
\text { Certificate }\end{array}$ & $\begin{array}{l}\text { Аспирантура (система } \\
\text { подготовки научных и } \\
\text { научно-педагогических } \\
\text { кадров при вузах } \\
\text { и научно-исследова- } \\
\text { тельских учреждениях) }\end{array}$ & $\begin{array}{l}\text { Graduate school: The Graduate } \\
\text { School of Education offers } 13 \text { dif- } \\
\text { ferent programs }\end{array}$ \\
\hline $\begin{array}{l}\text { Doctoral Training } \backslash \text { Postgraduate } \\
\text { (Postdoctoral) Level: Different } \\
\text { countries bave [...] different forms } \\
\text { of doctoral training }\end{array}$ & $\begin{array}{l}\text { Аокторантура (высшая } \\
\text { ступень в системе под- } \\
\text { готовки научных и на- } \\
\text { учно-педагогических } \\
\text { кадров) }\end{array}$ & $\begin{array}{l}\text { Doctoral program (study) } \\
\text { Postgraduate (Postdoctoral) Level: } \\
\text { Doctoral study at the university } \\
\text { means full immersion in one of the } \\
\text { world's most dynamic and influen- } \\
\text { tial intellectual communities }\end{array}$ \\
\hline $\begin{array}{l}\text { PhD student } \backslash \text { Doctoral student: As } \\
\text { a PhD student you are very much } \\
\text { part of our research. } \backslash \text { The doctoral } \\
\text { student will focus on Yorkshire over } \\
\text { some or all of the period 1500-1640 }\end{array}$ & Аспирант & $\begin{array}{l}\text { PhD student } \backslash \text { Doctoral student: } \\
\text { PhD students who request to borrow } \\
\text { loans are in a unique situation. } \\
\text { Doctoral students are eligible for } \\
\text { two grants per academic career }\end{array}$ \\
\hline $\begin{array}{l}\text { The Doctor of Philosophy }(\mathrm{PhD}) \text { : } \\
\text { The Doctor of Philosophy }(\mathrm{PhD}) \text { is } \\
\text { the major postgraduate research } \\
\text { degree }\end{array}$ & Аоктор наук & $\begin{array}{l}\text { The Doctor of Philosophy }(\mathrm{PhD}) \text { : } \\
\text { The doctor of philosophy }(\mathrm{PhD}) \text { is } \\
\text { primarily suited for individuals } \\
\text { with goals in public bealth research } \\
\text { or teaching }\end{array}$ \\
\hline
\end{tabular}


Названия образовательных программ в британских и американских вузах также имеют свои несоответствия. Само понятие «курс» в британском варианте выражено термином «level» или «course», а в американском - «program (study)», при этом американский дивергент свое нынешнее значение приобрел уже в конце XIX в., т. е. американизм является достаточно новым словом в отличие от бритицизма, который является французским заимствованием XII в. Также в британском английском используется понятие «training» в значении «докторантура», тогда как в американском английском неизменно выступает «program».

Терминология научного персонала университета отражена в табл. 4.

Как видим, термины, обозначающие профессорско-преподавательский состав, в основной своей массе совпадают, различия незначительны и касаются специфики

\section{НАУЧНО-ПЕААГОГИЧЕСКИЕ КААРЫ}

Таблица 4

UNIVERSITY TEACHING STAFF

Tabl. 4

\begin{tabular}{|c|c|c|}
\hline $\begin{array}{c}\text { Английский язькк } \\
\text { (британский Вариант) }\end{array}$ & Русский язык & $\begin{array}{c}\text { Английский язьк } \\
\text { (американский вариант) }\end{array}$ \\
\hline $\begin{array}{l}\text { Dean: Jeffrey S. Flier became the 21st } \\
\text { Dean of the Faculty of Medicine She } \\
\text { is the new dean of the Faculty of } \\
\text { Social Sciences }\end{array}$ & Аекан & $\begin{array}{l}\text { Dean: James E. Ryan is the 11th dean } \\
\text { of the Harvard Graduate School of } \\
\text { Education }\end{array}$ \\
\hline $\begin{array}{l}\text { Head of (sub)department: The } \\
\text { Department congratulates Dr. Mark } \\
\text { Pearce who bas been appointed Head } \\
\text { of the Department, starting August } \\
2008\end{array}$ & $\begin{array}{l}\text { Заведующий } \\
\text { кафедрой }\end{array}$ & $\begin{array}{l}\text { Chair of department: David Laibson } \\
\text { recently began bis term as the new } \\
\text { chair of the Economics Department in } \\
\text { July } 2015\end{array}$ \\
\hline $\begin{array}{l}\text { Professor: In his foreword Professor } \\
\text { Clark puts it explicitly }\end{array}$ & Профессор & $\begin{array}{l}\text { (Full) professor: President has } \\
\text { approved Maurice A. Smith for pro- } \\
\text { motion to the role of full professor }\end{array}$ \\
\hline $\begin{array}{l}\text { Associate professor: Associate } \\
\text { Professor in English Literature, } \\
\text { Faculty of Arts }\end{array}$ & Аоцент & $\begin{array}{l}\text { Associate professor: Associate } \\
\text { Professor of Civil and Environmental } \\
\text { Engineering }\end{array}$ \\
\hline $\begin{array}{l}\text { Teacher } \backslash \text { Assistant Professor } \backslash \\
\text { Lecturer } \backslash \text { Reader: Two academics at } \\
\text { The University of Nottingham bave } \\
\text { been named among the very best teach- } \\
\text { ers in UK bigher education. } \backslash \\
\text { Acclaimed writer joins University as } \\
\text { Assistant Professor of Creative } \\
\text { Writing. } \backslash \text { If the lecturer repeats, lists } \\
\text { or summarises information it is likely } \\
\text { to be important. } \backslash \text { Colin Leach is a } \\
\text { reader in Materials Science }\end{array}$ & Преподаватель & $\begin{array}{l}\text { Assistant professor } \backslash \text { Lecturer } \backslash \\
\text { Reader: He will be an assistant profes- } \\
\text { sor of applied physics at the } \\
\text { Department of Applied Physics. } \backslash \\
\text { Donbee Ham named an IEEE } \\
\text { (Institute of Electrical and } \\
\text { Electronics Engineers) Distinguished } \\
\text { Lecturer. } \backslash \text { She is a Reader in applied } \\
\text { economics }\end{array}$ \\
\hline
\end{tabular}


университетской структуры в рассматриваемых странах. Например, понятие «заведующий(-ая) кафедрой» в британском английском выражено вполне прозрачным словом «head», в американском же варианте это единица «сhair» с базовым значением «стул, трон» и новым, зафиксированным лишь в начале XX в., значением «председательствовать».

Структурные аналоги терминов наблюдаются при сравнении, например, бритицизма «professor» и американизма «full professor», т. е. термины разнятся лишь частично, как в данном случае, когда к основному слову добавлено определение «ull».

Интересная ситуация складывается при определении понятия «преподаватель». Широко распространенный термин «teacher» в лексике русскоговорящего человека находит свое применение лишь в британской лексике (см. табл. 4), тогда как изучение примеров употребления этой лексемы показало отсутствие этого термина в американском вузовском языке.

Теперь рассмотрим табл. 5 (с. 218), классифицирующую учащихся университета.

Как видим, американские университеты имеют своеобразную градацию студентов. Если это первокурсник, то «freshman», второкурсник - «sophomore», дальше идут «junior», «senior» и «upperclassman». Это лексико-семантические дивергенты с односторонней локальной маркированностью, поскольку британский английский не имеет дополнительных значений данных понятий.

\section{ЗАКАЮЧЕНИЕ}

Сопоставление академической терминологии двух наиболее распространенных вариантов английского языка в синхронно-сопоставительном плане показало, что различия носят частичный характер и свидетельствуют о слабовыраженной вариативности терминологических единиц, а основной объем понятий относится к общеанглийской лексике. Выявленные параллели свидетельствуют об общности лингвистической основы. Несоответствия как в плане выражения, так и в плане содержания вызваны автономным развитием, социокультурной спецификой обоих рассматриваемых языковых вариантов.

\section{СПИСОК АИТЕРАТУРЫ}

Амитриев, В. Е. (2010) К проблеме функционально-семантических особенностей терминологии в британском и американском вариантах английского языка // Studia Linguistica (Санкт-Петербург). № 11. С. 262-266.

Краткий терминологический словарь в области управления качеством высшего и среднего профессионального образования (2007) / В. В. Азарьева, О. А. Горленко, В. М. Григорьев, В. И. Круглов, Н. И. Прокопов, В. С. Соболев, С. О. Шапошников, И. В. Степанов, С. А. Степанов, В. В. Ященко. СПб. : ПИФ.com. 44 с.

Мариносян, Т. Э. (2014) Об унификации названий академических степеней и званий в классификационных системах в высшей школе и науке в условиях глобализации // Отечественная и зарубежная педагогика. № 4. С. 82-92.

Митчел, П. Аж., Маругина, Н. И. (2015) Проблема перевода русских и английских академических терминов (из опыта работы центра перевода ФИЯ ТГУ) // Вестник Томского государственного университета. № 3. С. 53-58.

Семенова, И. Б. (2011) Американские и британские термины банковского дела: миф или реальность // Филологические науки. № 2. С. 69-79. 
КААССИФИКАЦИЯ СТУАЕНТОВ

Таблича 5

CLASSIFICATION OF STUDENTS

Tabl. 5

\begin{tabular}{|c|c|c|}
\hline $\begin{array}{c}\text { Английский язъюк } \\
\text { (британский вариант) }\end{array}$ & Русский языю & $\begin{array}{c}\text { Английский язык } \\
\text { (американский вариант) }\end{array}$ \\
\hline $\begin{array}{l}\text { Student: Nicola is such a brilliant stu- } \\
\text { dent; I'd asked the Royal Ballet to } \\
\text { give ber an audition }\end{array}$ & Студент & $\begin{array}{l}\text { Student: The individual student will } \\
\text { submit an application }\end{array}$ \\
\hline $\begin{array}{l}\text { Full-time Student: Full-time students } \\
\text { made up nearly three-quarters of all } \\
\text { students in 2013-14, up from just over } \\
60 \%\end{array}$ & $\begin{array}{l}\text { Студент очного от- } \\
\text { деления }\end{array}$ & $\begin{array}{l}\text { Full-time Student: UConn's smallest } \\
\text { satellite campus bas only } 88 \text { full-time } \\
\text { students and just } 136 \text { total undergrad- } \\
\text { uates this spring }\end{array}$ \\
\hline $\begin{array}{l}\text { Part-time Student: Part-time students } \\
\text { faced multiple blows in terms of fund- } \\
\text { ing }\end{array}$ & $\begin{array}{l}\text { Студент заочного } \\
\text { или вечернего } \\
\text { отделения }\end{array}$ & $\begin{array}{l}\text { Part-time Student: The university } \\
\text { reopened for part-time students in } \\
\text { January this year }\end{array}$ \\
\hline $\begin{array}{l}\text { Student \Undergraduate: There are } \\
\text { currently } 24 \text { students registered on } \\
\text { the programme \anchester students } \\
\text { bost first undergraduate dental } \\
\text { research conference }\end{array}$ & $\begin{array}{l}\text { Студент первого } \\
\text { года обучения }\end{array}$ & $\begin{array}{l}\text { Freshman } \backslash \text { Student } \backslash \text { Undergraduate: } \\
\text { He is one of the fastest incoming } \\
\text { freshman in Columbia bistory. } \backslash \text { Our } \\
\text { student population is very diverse and } \\
\text { includes international students, } \\
\text { scholars, and faculty from over } 75 \\
\text { countries. } \backslash \text { Faculty and researchers } \\
\text { throughout the University are keen to } \\
\text { include undergraduates in their } \\
\text { research, where feasible }\end{array}$ \\
\hline $\begin{array}{l}\text { Second-year student } \backslash \text { Student } \backslash \\
\text { Undergraduate: He is a Second Year } \\
\text { Computer Science and Matb's } \\
\text { Student, who will bopefully go on } \\
\text { industrial experience next year }\end{array}$ & $\begin{array}{l}\text { Студент второго } \\
\text { года обучения }\end{array}$ & $\begin{array}{l}\text { Sophomore } \backslash \text { Student } \backslash \text { Undergraduate } \\
\text { Upperclassman: Limited to Music } \\
\text { majors (all freshman/sophomore } \\
\text { majors, and junior/senior majors not } \\
\text { in performance specialization) }\end{array}$ \\
\hline $\begin{array}{l}\text { Third-year student } \backslash \text { Student } \backslash \text { Under- } \\
\text { graduate: A third year student from } \\
\text { Pharmacy School bas been awarded } \\
\text { the Faculty of Medical and Human } \\
\text { Sciences Student of the Year Award }\end{array}$ & $\begin{array}{l}\text { Студент третьего } \\
\text { года обучения }\end{array}$ & $\begin{array}{l}\text { Junior \Student \Undergraduate } \\
\text { Upperclassman: Junior Year Abroad } \\
(J Y A) \text { students follow a program of } \\
\text { study }\end{array}$ \\
\hline $\begin{array}{l}\text { Fourth-year student } \backslash \text { Student } \backslash \\
\text { Undergraduate: Fourth year student } \\
\text { Saambra Lian gets article published in } \\
\text { Closer magazine }\end{array}$ & $\begin{array}{l}\text { Студент четвертого } \\
\text { года обучения }\end{array}$ & $\begin{array}{l}\text { Senior } \backslash \text { Student } \backslash \text { Undergraduate } \backslash \\
\text { Upperclassman: Scholarship for } \\
\text { Senior Women Students }\end{array}$ \\
\hline $\begin{array}{l}\text { Graduate } \backslash \text { Alumnus (pl. alumni): A } \\
\text { graduate in psychology, archaeology } \\
\text { or Oriental studies. } \backslash \text { He is married to } \\
\text { anotber Birmingham alumnus - Susan } \\
\text { Peters, who graduated in } 2000\end{array}$ & Выпускник & $\begin{array}{l}\text { Graduate } \backslash \text { Alumnus } \backslash \text { Upperclassman: } \\
\text { We must provide graduate students } \\
\text { more study space. } \backslash \text { UCL (University } \\
\text { of California) alumnus receives a } \\
\text { Prestigious Fulbright Award to the } \\
\text { US }\end{array}$ \\
\hline
\end{tabular}


Ожегов С. И. (2006) Толковый словарь русского языка : 80000 слов и фразеологических выражений / С. И. Ожегов и Н. Ю. Шведова. М. : А ТЕМП. 938 с.

Сулейманова, А. Р. (2009) Модели подготовки научно-педагогических кадров в Великобритании и США// Вестник Казанского государственного энергетического университета. № 3 . С. $134-148$.

Толковый словарь русского языка (2000) : в 4 т. / под ред. А. Н. Ушакова. Репр. изд. Т. 1. М. : ООО «Издательство АСТ». 848 с.

Швейцер, А. А. (1988) Теория перевода: Статус, проблемы, аспекты. М. : Наука. 215 с.

Аата поступления: 23.10.2016 г.

\section{THE ACADEMIC TERMINOLOGY OF BRITISH \\ AND AMERICAN ENGLISH \\ Z. KH. FAZlyeVA, N. O. SaMARKINA \\ KaZAN (Volga REGION) FEDERAL UNIVERSITY}

The article deals with comparative analysis of the terminology within the domain of higher education in the two most prevalent norms of the English language - British and American. The scientific community, including the one in Russia, faces some difficulties while interpreting and translating the terminology, because of variations of defining terms and some peculiarities in the educational system of the countries under analysis.

The main reason for such discrepancy could be the independent development of American English during a long historical period. In some cases it is impossible to find a direct analogue for a term, but some common standard for academic notions can be considered the benchmark for the research. Dictionaries do not normally provide the complete picture of the terminological differences, hence the research was also based upon English language corpus databases, as well as the scientific information from British and American universities' websites. It gave an opportunity to observe the functioning of language units in their natural, synchronic and actual linguistic environment.

The research material is arranged in tables, which clearly demonstrate the terminology of the British and American norms of the English language in the field of higher education. The performed analysis of the terminological units semantics has given an opportunity to define the lexical and semantic analogies and divergents in the terminology of the national norms under study.

Despite the unique characteristics of the development of the two English norms under research, their general linguistic base makes it impossible to achieve strongly defined variability of terminological units.

Keywords: higher school; the English language; British English; American English; comparative analysis; university structure; lexical and semantic variation; analogue; divergents

\section{REFERENCES}

Dmitriev, V. E. (2010) K probleme funktsional'no-semanticheskikh osobennostei terminologii v britanskom i amerikanskom variantakh angliiskogo iazyka. Studia Linguistica (Sankt-Peterburg), no. 11, pp. 262-266. (In Russ.).

Kratkii terminologicbeskii slovar'v oblasti upravleniia kachestvom vysshego $i$ srednego professional' nogo obrazovaniia (2007) / V. V. Azar'eva, O. A. Gorlenko, V. M. Grigor'ev, V. I. Kruglov, N. I. Prokopov, V. S. Sobolev, S. O. Shaposhnikov, I. V. Stepanov, S. A. Ste-panov and V. V. Iashchenko. St. Petersburg, PIF.com. 44 p. (In Russ.). 
Marinosian, T. E. (2014) Ob unifikatsii nazvanii akademicheskikh stepenei i zvanii v klassifikatsionnykh sistemakh $\mathrm{v}$ vysshei shkole i nauke v usloviiakh globalizatsii. Otechestvennaia $i$ zarubezhnaia pedagogika, no. 4, pp. 82-92. (In Russ.).

Mitchel, P. Dzh. and Marugina, N. I. (2015) Problema perevoda russkikh i angliiskikh akademicheskikh terminov (iz opyta raboty tsentra perevoda FIIa TGU). Vestnik Tomskogo gosudarstvennogo universiteta, no. 3, pp. 53-58. (In Russ.).

Semenova, I. B. (2011) Amerikanskie i britanskie terminy bankovskogo dela: mif ili real'nost'. Filologicheskie nauki, no. 2, pp. 69-79. (In Russ.).

Ozhegov S. I. (2006) Tolkovyi slovar' russkogo iazyka : 80000 slov i frazeologicheskikh vyrazhenii / S. I. Ozhegov and N. Iu. Shvedova. Moscow, A TEMP. 938 p. (In Russ.).

Suleimanova, A. R. (2009) Modeli podgotovki nauchno-pedagogicheskikh kadrov v Velikobritanii i SShA. Vestnik Kazanskogo gosudarstvennogo energeticheskogo universiteta, no. 3, pp. 134-148. (In Russ.).

Tolkovyi slovar' russkogo iazyka (2000) : in 4 vol., ed. D. N. Ushakova. Vol. 1. Moscow, OOO «Izdatel'stvo AST». 848 p. (In Russ.).

Shveitser, A. D. (1988) Teoriia perevoda: Status, problemy, aspekty. Moscow, Nauka. 215 p. (In Russ.).

Submission date: 23.10 .2016$.

Фазлыева Зульфия Ханифовна — кандидат филологических наук, доцент кафедры контрастивной дингвистики Института филологии и межкультурной коммуникации Казанского (Приволжского) федерального университета. Адрес: 420021, Россия, г. Казань, ул. Татарстан, д. 2. Тел.: +7 (843) 221-33-68. Эл. адрес: zulkin66@mail.ru

Самаркина Надежда Олеговна - кандидат филологических наук, доцент кафедры контрастивной лингвистики Института филологии и межкультурной коммуникации Казанского (Приволжского) федерального университета. Адрес: 420021, Россия, г. Казань, ул. Татарстан, д. 2. Тел.: +7 (843) 221-33-68. Эл. адрес: nadiya20021@yandex.ru

Fazlyeva Zulfiia Khanifovna, Candidate of Philology, Assistant Professor, Department of Contrastive Linguistics, Institute of Philology and Cross-cultural Communication of Kazan (Volga region) Federal University, Kazan. Postal address: 2 Tatarstan St., 420021 Kazan, Russian Federation. Tel.: +7 (843) 221-33-68. E-mail: zulkin66@mail.ru

Samarkina Nadezhda Olegovna, Candidate of Philology, Assistant Professor, Department of Contrastive Linguistics, Institute of Philology and Cross-cultural Communication of Kazan (Volga region) Federal University, Kazan. Postal address: 2 Tatarstan St., 420021 Kazan, Russian Federation. Tel.: +7 (843) 221-33-68. E-mail: nadiya20021@yandex.ru 